\title{
PENGARUH PERBEDAAN PENINGKATAN PERSENTASE PEMBERIAN CACING SUTERA MENURUT UMUR LARVA TERHADAP KELANGSUNGAN HIDUP DAN PERTUMBUHAN LARVA IKAN BAUNG (Hemibagrus nemurus)
}

\section{Effect of Differences Increasing Percentage of Salt Work According to Age Larva on Life Continuation Growth of Larva Fish (Hemibagrus nemurus)}

\author{
Ahmad Syafitra, Agusnimar dan Rosyadi \\ Fakultas Pertanian Universitas Islam Riau, Jl. Kaharuddin Nasution No. 113 Pekanbaru \\ [Diterima Maret 2018; Disetujui April 2018]
}

\begin{abstract}
This research aims to know the effect of the difference in percentage increase of silkworm by larvae age on the survival and growth of larvae (Hemibagrus nemurus). The method used is experimental method using Completely Random Design (RAL) with 4 treatments and 3 replications namely, P1 (Improvement Percentage 3\%, 5\% and 7\%), P2 (3\%, 6\% and 9\% Percentage increase), P3 $(3 \%, 7 \%$ and $11 \%)$ P4 (3\%, 8\% and 13\%). The test fish used were bamboo larvae that were 7 days old with an average weight of $0.0004 \mathrm{gr}$ and an average length of $0.8 \mathrm{~cm}$. Larva fish obtained from the spawning in the Seed Fish Hall (BBI) Faculty of Agriculture, Islamic University of Riau Pekanbaru. The container used is 10 liters or 12 liters water capacity. The result of the research showed the best survival percentage was on P4 treatment, which is $96,00 \%$, followed by P3 treatment that is $94,67 \%, \mathrm{P} 2$ treatment is $90,67 \%$ and lowest is $\mathrm{P} 1$, that is $86,67 \%$. The absolute weight growth and the highest absolute length were at treatment (P4) with weighing $0.30 \mathrm{gr}$ and length $3.35 \mathrm{~cm}$, followed by treatment (P3) that is 0.32 gr and length $3.02 \mathrm{~cm},(\mathrm{P} 2)$ weighing $0.31 \mathrm{gr}$ and length of $2.84 \mathrm{~cm},(\mathrm{P} 1)$ weighing $0.30 \mathrm{gr}$ and length $2.77 \mathrm{~cm}$. The highest growth rate of daily weight was also found in treatment $(\mathrm{P} 4)$, ie $11 \%$, (P3) 10,46\%, (P2) 10,24\%, and the lowest in treatment (P1) $10,12 \%$.
\end{abstract}

Keywords: Silk worms, Larvae, Baung fish

\begin{abstract}
ABSTRAK
Penelitian bertujuan untuk mengetahui pengaruh perbedaan peningkatan persentase pemberian cacing sutera menurut umur larva terhadap kelangsungan hidup dan pertumbuhan larva ikan baung (hemibagrus nemurus) Metode yang digunakan adalah metode ekperimen menggunakan Rancangan Acak Lengkap (RAL) dengan 4 perlakuan dan 3 ulangan yaitu, P1 (Peningkatan Persentase 3\%, 5\% dan 7\%), P2 (Peningkatan Persentase 3\%, 6\% dan 9\%), P3 (Peningkatan Persentase 3\%, 7\% dan 11\%) P4 (Peningkatan Persentase 3\%, 8\% dan 13\%). Ikan uji yang digunakan adalah larva ikan baung yang berumur 7 hari dengan berat rata-rata 0,0004 gr dan panjang rata-rata $0,8 \mathrm{~cm}$. Larva ikan baung diperoleh dari hasil pemijahan di Balai Benih Ikan (BBI) Fakultas Pertanian Universitas Islam Riau Pekanbaru. Wadah yang digunakan adalah toples kapasitas 10 liter sebanyak 12 buah. Dari hasil penelitian diperoleh persentase kelangsungan hidup yang terbaik pada perlakuan P4, yaitu sebesar 96,00\%, disusul oleh perlakuan P3 yaitu 94,67\%, selanjutnya perlakuan P2, yaitu $90,67 \%$ dan yang terendah pada perlakuan P1, yaitu $86,67 \%$. Pertumbuhan berat mutlak dan panjang mutlak tertinggi pada perlakuan (P4) yaitu seberat $0,30 \mathrm{gr}$ dan panjang $3,35 \mathrm{~cm}$, disusul dengan perlakuan (P3) yaitu 0,32 gr dan panjang $3,02 \mathrm{~cm}$, (P2) seberat 0,31 gr dan panjang $2,84 \mathrm{~cm}$, (P1) dengan berat 0,30 gr dan panjang $2,77 \mathrm{~cm}$. Laju pertumbuhan berat harian yang tertinggi juga terdapat pada perlakuan (P4) yaitu $11 \%$, (P3) $10,46 \%$, (P2) $10,24 \%$, dan yang terendah pada perlakuan (P1) 10,12\%.
\end{abstract}

Kata kunci: Cacing Sutra, Larva, Ikan Baung 


\section{PENDAHULUAN}

Ikan Baung (H. nemurus) merupakan salah satu jenis ikan air tawar endemisitas yang berasal dari Suku Bagridae yang banyak dijumpai di perairan sungai di Pulau Sumatera, Jawa dan Kalimatan (Tang, 2003).

Ikan Baung termasuk ikan yang memiliki nilai ekonomis yang cukup tinggi, oleh karena itu ikan tersebut menjadi target utama penangkapan oleh para nelayan, sehingga intensitas penangkapan ikan tersebut terus meningkat, sebagai akibatnya populasi ikan baung di perairan umum terus menurun.

Menurut Alawi (1995) untuk mempertahankan keadaan populasi dan pendapatan nelayan salah satu upaya yang secara teknis dan ekonomis dapat dilakukan untuk menunjang kegiatan budidaya adalah dengan melakukan usaha pembenihan ikan. Masalah yang sering dihadapai dalam usaha pembenihan ikan adalah tingginya tingkat mortalitas ikan pada saat fase larva dan benih, terutama pada saat larva kehabisan kuning telur. Menurut Djajadiredja dalam Hayati (2004) kematian ikan yang terbesar umumnya terjadi sejak persediaan makanan pada kantong kuning telur habis sampai ukuran benih.

Salah satu faktor penyebab tingginya mortalitas larva dan benih ikan baung adalah ketersedian pakan, diantaranya pakan alami. Jenis pakan alami yang terbaik untuk benih ikan setelah berumur 5 hari ialah cacing sutra $(T$. tubifex). Pada umur 11 - 30 hari perkembangan saluran pencernaan sudah lengkap sehingga pada saat tersebut cacing sutera yang panjangnya $20 \mathrm{~mm}$ dapat dimanfaatkan oleh benih ikan baung dan lebih banyak dikonsumsi (Tang et al., 2000). Cacing sutera sangat baik diberikan pada benih karena mempunyai kadar protein yang sangat tinggi, sehingga dapat mempercepat pertumbuhan dan kelulushidupan benih ikan baung. Salah satu cara pemberian cacing sutera pada larva ikan yaitu melalui persentase karena dengan begitu pakan yang berikan sesuai dengan berat tubuh ikan.

Beberapa penelitian tentang pemberian pakan alami cacing sutera pada larva ikan diantaranya Adam (2013), persentase cacing sutera yang terbaik untuk larva ikan lele sangkuriang adalah $7 \%$. Sedangkan Mapaliey et al., (2013) persentase cacing sutera yang terbaik untuk kelulushidupan dan pertumbuhan panjang serta berat larva ikan patin siam adalah $15 \%$. Persentase pakan untuk benih lebih sering dibandingkan dengan ikan besar, karena benih lebih banyak mengkonsumsi pakan alami. persentase pakan untuk ikan yang masih kecil biasanya $3-7 \%$ dalam sehari dan waktu pemberian pakan ditetapkan dengan memperhatikan nafsu makan ikan (Dharmawan dalam Adam, 2013).

Namun jumlah pakan yang diberi perlu ditingkatkan sesuai dengan bertambahnya berat larva atau benih ikan. Menurut Anonim (2009) laju pertumbuhan berhubungan dengan ketepatan antara jumlah pakan yang diberikan dengan kapasitas lambung atau sesuai dengan waktu ikan membutuhkan pakan, perlu diperhatikan karena pada saat itu ikan sudah dalam kondisi lapar.

Sementara pada penelitian Adam (2013) dan Mapaliey et al., (2013) persentase pakan yang diberikan belum ditingkatkan, sehingga perlu penambahan jumlah persentase pakan pada setiap kali pengukuran ikan, agar sesuai dengan berat tubuh ikan. Berdasarkan hal tersebut penulis ingin melakukan penelitian tentang Pengaruh perbedaan peningkatan persentase pemberian cacing sutera menurut umur larva terhadap kelangsungan hidup dan pertumbuhan larva ikan baung (H. nemurus).

\section{METODE PENELITIAN}

Penelitian ini dilaksanakan selama 21 hari yaitu dimulai pada tanggal 11 sampai 31 Januari 2018. Bertempat di Balai Benih Ikan (BBI) Fakultas Pertanian Universitas Islam Riau Pekanbaru.

Bahan yang digunakan dalam penelitian ini adalah :

1. Larva ikan baung yang telah berumur 7 hari didapat dari hasil pemijahan secara buatan di BBI UIR, dengan berat awal 0,04 gr dan panjang $0,8 \mathrm{~cm}$.

2. Pakan yang diberikan pada ikan uji yaitu pakan alami berupa cacing sutera $(T$. tubifex) yang diperoleh dari pengumpul di daerah Sail Pekanbaru.

3. Air yang digunakan dalam penelitian ini berasal dari sumur bor dan sudah diendapkan selama 3 hari sebelum dipakai untuk media hidup ikan uji.

Peralatan yang digunakan dalam penelitian ini adalah:

1. Toples ukuran 10 liter sebanyak 12 buah digunakan sebagai wadah penelitian. 
2. Timbangan dengan tingkat ketelitian 0.01 mg yang digunakan untuk menimbang berat ikan uji.

3. Penggaris untuk pengukuran panjang ikan uji.

4. Aerasi dengan perlengkapannya yang berguna untuk mensuplay oksigen.

5. Tangguk besar dan kecil untuk menyerok ikan uji.

6. Thermometer digunakan untuk mengukur suhu air.

7. Kertas lakmus untuk mengukur $\mathrm{pH}$ air.

8. DO meter digunakan untuk mengukur oksigen terlarut dan $\mathrm{NH} 3$.

Penelitian ini dilakukan melalui serangkaian kegiatan mulai dari persiapan wadah, penebaran larva ikan baung, pemberian makanan, pengukuran kualitas air, pengukuran larva dan penghitungan jumlah larva ikan.

a. Persiapan Wadah

Sebelum penelitian dilakukan, wadah yang digunakan dalam penelitian ini dibersihkan dengan menggunakan larutan PK (Kalium permanganat). Setelah itu wadah diisi air sebanyak 5 liter dan disusun sesuai hasil pengacakan kemudian wadah diberi aerasi untuk mensuplay oksigen. Selanjutnya setiap wadah diberi lebel sesuai hasil pengacakan perlakuan.

\section{b. Penebaran Larva}

Larva ikan baung yang digunakan dalam penelitian ini diperoleh dari hasil pemijahan induk ikan baung secara buatan dengan menggunakan hormone LHRH (ovaprim) dengan dosis $1,5 \mathrm{cc}$. telur hasil pemijahan ditetaskan di dalam bak fiber. Setelah telur menetas kemudian larva dipelihara sampai berumur 7 hari, setelah itu dilakukan pengukuran berat dan panjang larva ikan kemudian ditebarkan kedalam wadah penelitian dengan kepadatan 10 ekor/liter.

c. Pemberian Pakan (T. tubifex)

Pakan yang digunakan dalam penelitian ini adalah cacing sutera yang berasal dari pengumpul di daerah Sail Pekanbaru. Sebelum diberikan terlebih dahulu cacing sutera dipotong halus kemudian dicuci dengan air untuk membersihkan sisa-sisa darahnya. Cacing sutera yang telah dipotong kemudian di timbang sesuai dengan persentase masing-masing perlakuan, yaitu dengan cara menghitung berat total ikan yang ada di dalam wadah, dibagi $100 \mathrm{x}$ persentase pakan pada setiap perlakuan.

d. Pengamatan dan Pengukuran Parameter Kualitas Air

Pengamatan ini dilakukan untuk mengetahui perubahan yang terjadi pada kualitas air disetiap wadah penelitian, pengamatan kualitas air yang dilakukan meliputi pengukuran suhu, $\mathrm{pH}$, DO dan $\mathrm{NH}$, untuk pengukuran suhu dilakukan pada pagi, siang, sore dan malam hari, sedangkan $\mathrm{pH}$ diukur seminggu sekali, dimulai pada awal hingga akhir penelitian, kemudian $\mathrm{DO}$ dan $\mathrm{NH} 3$ diukur pada awal dan akhir penelitian.

e. Pengukuran dan Penghitungan Jumlah Larva Ikan

Pengukuran berat larva ikan dilakukan dengan cara diambil sebanyak 10 ekor dari jumlah seluruh ikan yang ada di dalam wadah penelitian, kemudian ditimbang, selanjutnya pengukuran panjang menggunakan 3 ekor ikan lalu diukur panjangnya menggunakan penggaris. Sedangkan untuk penghitungan jumlah larva ikan dilakukan pada setiap kali pengukuran. Semua pengukuran berat, panjang dan jumlah larva ikan baung dilakukan setiap 7 hari sekali (per minggu).

Penelitian ini menggunakan rancangan acak lengkap (RAL) yang terdiri dari 4 perlakuan dan 3 ulangan. Dimana perlakuan yang digunakan adalah sebagai berikut :

\begin{tabular}{|c|c|c|c|}
\hline \multirow{2}{*}{ Perlakuan } & \multicolumn{3}{|c|}{ Umur Larva (Hari) } \\
\cline { 2 - 4 } & $1-7$ & $7-14$ & $14-21$ \\
\hline P1 & $3 \%$ & $5 \%$ & $7 \%$ \\
\hline P2 & $3 \%$ & $6 \%$ & $9 \%$ \\
\hline P3 & $3 \%$ & $7 \%$ & $11 \%$ \\
\hline P4 & $3 \%$ & $8 \%$ & $13 \%$ \\
\hline
\end{tabular}

Keterangan:

P1 (Peningkatan Persentase 3\%, 5\% dan 7\%), P2 (Peningkatan Persentase 3\%, 6\% dan 9\%), P3(Peningkatan Persentase 3\%, 7\% dan 11\%) P4 (Peningkatan Persentase 3\%, 8\% dan 13\%)

\section{HASIL DAN PEMBAHASAN}

\section{Kelangsungan Hidup}

Persentase rata-rata kelangsungan hidup larva ikan Baung pada masing-masing perlakuan dapat dilihat pada Gambar 4.1. 


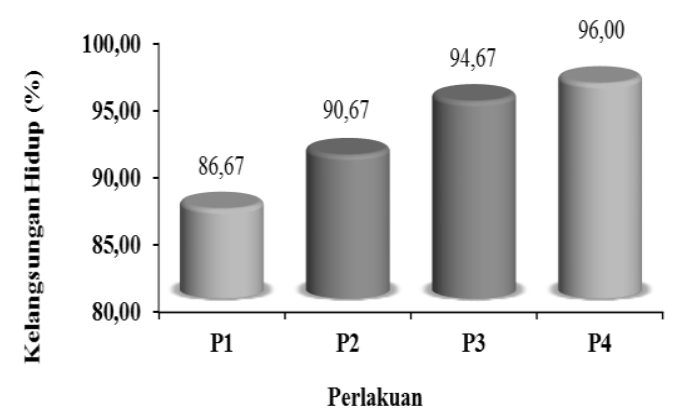

Gambar 1. Grafik Rata-rata Kelangsungan Hidup Larva Ikan Baung (Hemibagrus nemurus) Selama Penelitian (\%)

Berdasarkan Gambar 1. dapat dilihat bahwa tingkat kelulushidupan terbaik pada perlakuan P4 dan terendah terdapat pada perlakuan P1. Hal ini dikarenakan jumlah persentase pemberian cacing pada P4 lebih tinggi dari pada P1. Kelangsungan hidup larva ikan di determinasi oleh kombinasi berbagai faktor yang meliputi, nutrisi larva, lingkungan, imunitas kualitas air dan padat tebar (Hearth dan Atapaththu, 2013).

Menurut Adam (2013) menyatakan bahwa pemberian pakan alami pada pendederan satu sebaiknya diberikan semaximal mungkin sehingga tidak terjadinya persaingan makanan, dan perbedaan ukuran benih ikan. Karena kedua masalah ini akan mengakibatkan mortalitas dalam jumlah yang cukup besar bahakan dapat mencapai $75 \%$. Hal ini sesuai dengan Dharmawan (2013), menyatakan bahwa pemberian pakan disesuaikan dengan kebutuhan. Artinya, pakan yang diberikan jangan sampai tersisa banyak. Jika hal ini terjadi, pakan sisa tersebut akan membusuk dan dapat menurunkan kualitas air. Namun, disarankan pemberian pakan diberikan secara adlibitum atau tidak terbatas selama benih masih mau makan. Selain itu Fauzi (2013), menyatakan bahwa lele mempunyai sifat yang sangat rakus terhadap makanannya. Tak jarang pada pembudidayaannya muncul sifat kanibalisme. Jika pada pembudidayaannya pemberian pakan tersebut kurang dari takarannya, maka tidak menutup kemungkinan akan terjadi kanibalisme.

\section{Pertumbuhan Berat Mutlak}

Hasil pengukuran pertambahan rata-rata berat mutlak larva ikan baung selama penelitian pada masing-masing perlakuan.

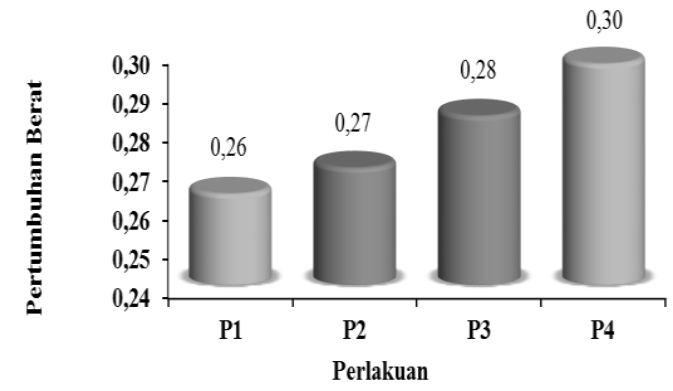

Gambar 2. Grafik Rata-rata Pertumbuhan Berat Mutlak Larva Ikan Baung (H. nemurus) selama penelitian (gr)

Berdasarkan Gambar 2. diatas terlihat bahwa pertumbuhan berat mutlak tertinggi terjadi pada perlakuan P4 sebesar 0,30 gr, sedangkan pertumbuhan mutlak terendah terdapat pada perlakuan P1 sebesar 0,26 gr. Hal tersebut disebabkan oleh pemberian cacing sutera pada perlakuan P4 lebih tinggi dibandingkan dengan perlakuan P1 yaitu pada perlakuan $\mathrm{P} 4$ penambahan persentase pemberian cacing sutera mencapai $13 \%$ sedangkan pada perlakuan P1 mencapai 7\%. Hal ini disebabkan oleh jumlah pakan yang diberikan lebih tinggi sehingga ikan dapat memanfaatkan kandungan protein dari Tubifex yang sangat tinggi mencapai $57 \%$ untuk pertumbuhan. Jadi dapat disimpulkan semakin banyak tubifex yang diberikan maka semakin bagus untuk pertumbuhan ikan baung.

Sari et al., (2015) menyatakan bahwa semakin banyak pakan yang tersedia dalam wadah pemeliharan maka peluang dikonsumsinya pakan tersebut akan semakin tinggi, sehingga menyebabkan terjadinya pertumbuhan benih ikan yang semakin tinggi pula. Keadaan ini erat kaitannya dengan jumlah energi yang dihasilkan dari proses pencernaan makanan. Seperti yang dijelaskan Huet (1973) bahwa pertumbuhan baru akan terjadi bila energi makanan yang dimakan lebih banyak dari pada yang diperlukan untuk pemeliharaan tubuh.

Makanan mempunyai peranan yang sangat penting dalam pertumbuhan individu. Untuk merangsang pertumbuhan yang optimal diperlukan jumlah dan mutu makanan yang tersedia dalam keadaan yang cukup serta sesuai dengan kondisi perairan (Asmawi, 1987).

\section{Pertumbuhan Panjang Mutlak}

Selain pertumbuhan berat pada penelitian ini juga diukur mengenai pertumbuhan panjang larva ikan baung pada 
masing-masing perlakuan. Hasil pengukuran pertumbuhan panjang mutlak larva ikan baung selama penelitian pada masing-masing.

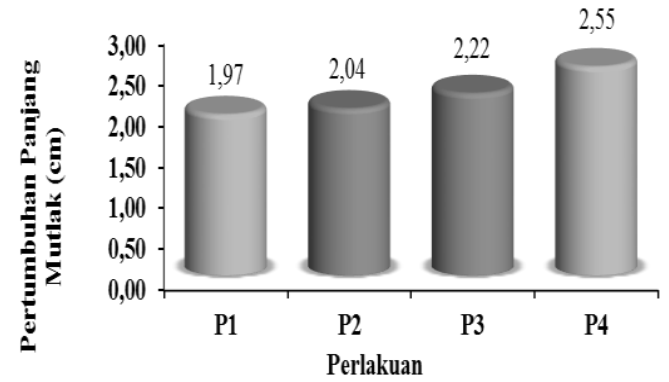

Gambar 3. Grafik Rata-rata Pertumbuhan Panjang Mutlak Larva Ikan Baung (H. nemurus) Selama Penelitian (cm)

Berdasarkan gambar diatas dapat dilihat bahwa pertumbuhan panjang mutlak berbeda pada setiap masing - masing perlakuan. Pertumbuhan panjang mutlak terbaik didapat pada perlakuan P4 sekitar $2,55 \mathrm{~cm}$, selanjutnya pada perlakuan P3 sekitar 2,22 cm, kemudian dilanjutkan pada perlakuan P2 sekitar 2,04 dan selanjutnya pertumbuhan panjang mutlak terendah terdapat pada perlakuan P1 sekitar 1,97 $\mathrm{cm}$. Pertumbuhan panjang mutlak terbaik pada perlakuan P4 dikarenakan pemberian cacing sutera lebih tinggi dibandingkan dengan perlakuan lainnya. Dimana semakin banyak pemberian cacing sutera maka semakin baik untuk pertumbuhan larva ikan baung.

Lovell, (1989) menyatakan bahwa ikan akan tumbuh apa bila nutrisi pakan yang dicerna dan diserap oleh tubuh ikan lebih besar dari jumlah yang diperlukan untuk memelihara tubuhnya. Sedangkan Huet dalam Amali (2007), menyatakan bahwa pertumbuhan ikan dipengaruhi oleh faktor internal yang meliputi keturunan, umur, ketahanan terhadap penyakit dan kemampuan untuk memanfaatkan makanan. Sedangkan faktor eksternal yang meliputi suhu air, ruang gerak, kualitas air, jumlah dan mutu makanan yang tepat waktu dan jumlah yang cukup harus diperhatikan.

Tang (2007), menegaskan pertumbuhan ikan dipengaruhi oleh beberapa faktor, salah satunya adalah kualitas dan kuantitas pakan yang diberikan..

\section{Laju Pertumbuhan Berat Harian}

Untuk melihat kecepatan pertumbuhan larva ikan baung selama penelitian, dilakukan penghitungan laju pertumbuhan berat harian larva ikan baung

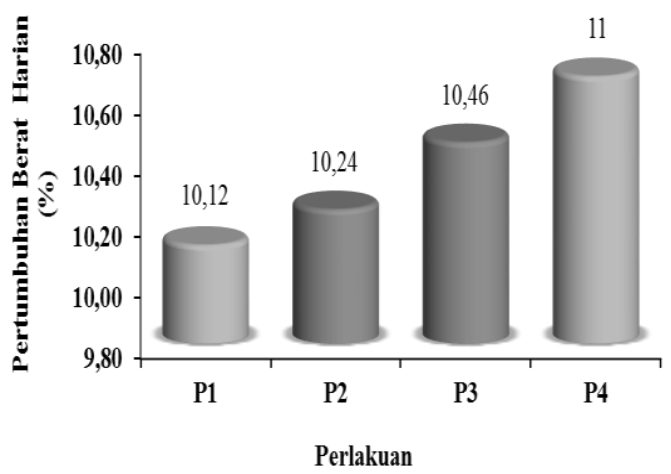

Gambar 4. Grafik Rata-rata Laju Pertumbuhan Berat Harian Larva Ikan Baung (H. nemurus) Selama Penelitian (\%).

Berdasarkan Gambar 4.4. diatas terlihat rata-rata laju pertumbuhan harian larva ikan baung terbaik terdapat pada perlakuan P4 dengan laju pertumbuhan harian sebesar $11 \mathrm{gr}$, diikuti oleh perlakuan P3 laju pertumbuhan harian sebesar 10,46 gr, selanjutnya dilanjutkan pada perlakuan P2 dengan laju pertumbuhan harian sebesar 10,24 gr sedangkan laju pertumbuhan harian terendah terdapat pada perlakuan P1 dengan angka 10,12 gr. Pada perlakuan P4 mendapatkan hasil tertiggi disebabkan karena pemberian peningkatan persentase cacing sutera yang tinggi, maka semakin banyak pemberian cacing sutera akan semakin baik untuk pertumbuhan ikan.

$$
\text { Menurut Weartherley }
$$
pertumbuhan adalah perubahan ukuran baik berat, panjang, maupun volume sesuai dengan pertambahan waktu. Selanjutnya Huet (1973) menyatakan bahwa pertumbuhan ikan dipengaruhi oleh faktor internal yang meliputi keturunan, umur, ketahanan terhadap penyakit dan kemampuan untuk memanfaatkan makanan buatan, sedangkan faktor eksternal meliputi suhu air, besarnya ruang gerak, kualitas air, jumlah dan mutu makanan.

Suhenda (2010) pemberian ransum harian yang tepat pada ikan untuk mencapai pertumbuhan yang optimal adalah sebesar $30 \%$. Jumlah makanan yang akan diberikan pada ikan haruslah disesuaikan dengan jumlah ikan yang sedang dipelihara, jika jumlah makanan yang diberikan terlalu sedikit dapat mempengaruhi pertumbuhan ikan yang sedang dipelihara.

Dari hasil analisis variansi yang dilakukan diperoleh $\mathrm{F}$ hitung 8,63 > F tabel 4,07 (0.05) menunjukkan bahwa pemberian penambahan 
persentase yang berbeda nyata terhadap laju pertumbuhan harian larva ikan baung.

\section{KESIMPULAN}

1. Tingkat kelangsungan hidup tertinggi mencapai 96\% untuk perlakuan P4, 94\% untuk perlakuan $\mathrm{P} 3,90 \%$ untuk perlakuan $\mathrm{P} 2$, dan $86 \%$ untuk perlakun $\mathrm{P} 1$.

2. Berat mutlak untuk masing-masing perlakuan yaitu perlakuan P1 sebesar 0,26 gr , perlakuan P2 sebesar 0,27 gr, perlakuan p3 sebesar 0,28 gr, dan perlakuan P4 mencapai 0,30 gram dari berat awal tebar sebesar 0,04 gram.

3. Pertumbuhan panjang mutlak yang terbaik pada perlakuan (P4) yaitu $2,55 \mathrm{~cm}$ dan yang terendah pada perlakuan $(\mathrm{P} 1)$ yaitu $1,97 \mathrm{~cm}$.

4. Laju pertumbuhan berat harian yang tertinggi terdapat pada perlakuan P4 yaitu 11 gram dan yang terendah terdapat pada perlakuan P1 yaitu 10,12 gram.

\section{DAFTAR PUSTAKA}

Adam, Y. 2013. Pengaruh Pemberian Cacing Sutera (Tubifex $s p$ ), dengan Dosis yang Berbeda terhadap Pertumbuhan Benih Ikan Lele Sangkuriang (Clarias sp). Di Balai Pengembangan Budidaya Ikan Air Tawar (BPBIAT). Provinsi Gorontalo. 32 hal.

Alawi, H. 1995. Budidaya Ikan Baung (Macrones nemurus C.V) dalam Keramba Terapung di Sungai Kampar dengan Padat Tebar Berbeda. Lembaga Penelitian Universitas Riau, Pekanbaru. 36 hal.

Amali, A. 2007. Pengaruh Pemberian Artemia $s p$ dengan Jumlah yang Berbeda terhadap Kelulus hidupan dan Pertumbuhan Ikan Selais (Cryptoterus lais). Skripsi. Fakultas Pertanian Universitas Islam Riau. Pekanbaru. 52 Hal.

Anonim, 2009. http://fcrranigr.blogspot.co.id/2012/05/konv ersi-pakan-perikanan.html. Diakses 10 Januari 2018.

Asmawi, S. 1987. Pemeliharaan Ikan dalam Keramba. Gramedia Jakarta. 82 hal.

Dharmawan, Bagas.2013. Usaha Pembutn Pakan Ikan konsumsi. Puataka Baru Press. Yogyakarta.
Fauzi dan Faisal, N. 2013. Pasti Panen Lele. Sahabat. Klaten rata-rata

Hayati, U. 2004. Pengaruh Persentase Pemberian T. tubifex dan Pelet Udang terhadap Pertumbuhan dan Kelulus Hidupan Benih Ikan Baung (Mystus nemurus). Skripsi Fakultas Pertanian Jurusan Budidaya Perikanan. UIR. Pekanbaru. 67 halaman.

Hearth, S, S. K.S.S. Atapaththu. 2013. Sudden Weaming Of Anggel Fish Pterophyllum Scalare (Lichtenstein) (Pisces : Cichlidae) larvae brine shrimp (Artemia sp) nauplii to formulated larva feed. Springer Plus 2: 102

Huet, M. 1973. Text Book of Fish Culture Breeding and Cultivation of Fish. Fishing News (Book) Ltd, London. 436 halaman.

Lovell, T. 1989. Nutrition and Feeding of Fish . New York: Auburn University $267 \mathrm{p}$

Mapaliey, N, H. Sinjal dan E. Lengkong. 2013. Pengaruh Pemberian Pakan Cacing Sutra (Tubifex sp) Dosis Berbeda terhadap Kelulus Hidupan dan Pertumbuhan Larva Ikan Patin Siam (Pangasianodon hypophthalmus). Buletin Sariputra. Di Hatchery Balai Budidaya Air Tawar (BBAT). Tatelu. Vol. 4 (3).

Sari, I.J. 2015. Pengaruh Dosis Pemberian Pakan Tubifex sp Berbeda Terhadap Pertumbuhan Benih Ikan Sidat di Balai Benih Ikan Kota Gorontalo. Jurnal Ilmiah Perikanan dan Kelautan. Fakultas Perikanan dan Ilmu Kelautan Universitas Negeri Gorontalo. Hal 76.

Suhenda, N. 2010. Pengaruh Tingkat Pemberian Rasum Harian terhadap Petumbuhan Benih Ikan Mas (Cyprinus carpio L) Bulletin Penelitian Perikanan dan Pengembangan Pertanian IPB, Bogor. 47 hal.

Tang, U.M., R. Affandi, Widjajakusuma, H. Setianto dan M.F Rahardjo. 2000. Aspek Biologi dan Kebutuhan Lingkungan Benih Ikan Baung. Dalam Disertasi Program Pasca Sarjana. Institut Pertanian Bogor.

Tang, U, M. 2003. Budidaya Ikan Konsumsi. Kanisius. Yogyakarta. 55 halaman.

Tang, U, M. 2007. Teknik Budidaya Ikan Baung. Kanasius Yogyakarta. 85 hal.

Weartherly, A. H. 1972. Growth and Ecology of Fish Population. Academic Press, London. 293 halaman. 